\title{
APPLICATION OF DNA MARKERS TO CLINICAL GENETICS
}

\author{
Yusuke NAKAMURA \\ Laboratory of Molecular Medicine, Institute of Medical Science, \\ The University of Tokyo, 4-6-1 Shirokanedai, \\ Minato-ku, Tokya 108, Japan
}

\begin{abstract}
Summary DNA technology using DNA sequence polymorphisms has brought a new system to the fields of medicine and forensic science, especially for the studies of genetic diseases and tumor suppressor genes, and for identification of individuals for forensic purposes. Linkage analysis based on segregation of polymorphic alleles in affected families has contributed to identification of many genetic diseases. We isolated a large number of polymorphic DNA markers, called VNTR (variable number of tandem repeat) markers and identified the APC gene that is responsible for familial adenomatous polyposis (FAP) by means of a so-called "positional cloning" and characterized germline and somatic mutations of the APC gene in colorectal cancer patients. In addition, we have applied genetic information during colorectal carcinogenesis to sensitive diagnosis of lymph-node metastasis of colorectal cancer.
\end{abstract}

Key Words RFLP, VNTR, linkage analysis, positional cloning, APC

\section{Polymorphic DNA markers}

Segregation studies based on polymorphic DNA markers, normal variations in DNA at many sites in the human genome, often allow us to distinguish whether a chromosome is of maternal or paternal origin. When that is possible, we can follow the inheritance of a gene that is known only by a phenotype that is segregating in a family, if the phenotype co-segregates with a polymorphic "marker" locus. Co-segregation, or "linkage," depends on physical proximity on a chromosome between the marker and the unknown gene. Genetic linkage analysis using this powerful property of normal variations has been contributing to isolate genes responsible for human genetic diseases such as Duchenne muscular dystrophy, cystic fibrosis, polycystic kidney disease, and familial adenomatous polyposis.

Conventional polymorphic DNA loci consisted of only two possible alleles, generated by a substitution of one nucleotide for another in human genomic DNA, 
at a site recognized for cleavage by a bacterial endonuclease ("restriction enzyme"). We developed another type of RFLP, known as a VNTR (Variable Number of Tandem Repeat) (Nakamura et al., 1987, 1988a), the second-generation polymorphic DNA marker, that is generated by variation from one individual to another in the number of tandemly-repeated sequences at a particular locus. Because the number of different alleles possible in the population can be large at such a locus, VNTRs are very informative in a linkage study. VNTRs are also helpful in forensic studies because of their highly polymorphic nature (Odelberg et al., 1989; Kasai et al., 1990), and they are being used in clinical settings to monitor recipients of bone marrow transplants (Gatti et al., 1989). However, in recent years, a huge number of the third-generation polymorphic DNA marker, microsatellite DNA markers were identified and have been used for linkage analysis (Gyapay et al., 1994). The microsatellite markers are generated by variation in the number of short tandemly-repeated sequences like $\mathrm{CA}, \mathrm{CT}$, or $\mathrm{CAA}$ at a particular locus, and are amplified by the polymerase chain reaction.

\section{Construction of chromosomal maps}

For the construction of a genetic linkage map that will be useful in detecting the location of a genetic defect segregating in a family, we need to estimate the distance between DNA markers. Such estimates derive from the frequency of recombination events between pairs of markers. During meiosis, the homologous chromosomes line up in pairs; crossing-over of segments of DNA occurs between the homologs, and this exchange of material (recombination) produces chimeric chromosomes, a patchwork of DNA segments derived from each parent.

During one meiosis, an estimated 30 recombination events occur throughout the genome. From this phenomenon and the estimated size of the human genome $\left(3 \times 10^{9}\right.$ base pairs), we can calculate roughly that a $1 \%$ frequency of recombination between two markers reflects an average of $1,000 \mathrm{~kb}$, or 1 million nucleotide base pairs, of physical distance on a chromosome. Our analysis of genotypic data for DNA markers in a large number of 3-generation families, using a sophisticated computer program, has produced genetic linkage maps for almost all human chromosomes (O'Connell et al., 1989a, b, c; Lathrop et al., 1988a, b, 1989; Nakamura et al., 1988b, c, d, e, 1989a, b; White et al., 1989; Julier et al., 1990a, b; Yamakawa et al., 1991a; NIH/CEPH Collaborative Mapping Group, 1992).

In addition to genetic linkage maps, we have constructed cytogenetic chromosomal maps using fluorescent in situ hybridization (FISH) technique. We constructed cosmid libraries from human-mouse somatic hybrid cell lines, that contained single human chromosome as the only human complement. By colony hybridization with labeled total human DNA as a probe, we selected chromosome-specific cosmid clones and constructed high-resolution cytogenetic maps with the average distance between markers of $250 \mathrm{~kb}-1 \mathrm{Mb}$. A total of more than 3,300 genomic cosmid markers have so far been mapped on chromosomes 1, 2, 3, 
5, 6, 8, 9, 11, 12, and 17 (Yamakawa et al., 1991b; Hori et al., 1992; Takahashi et al., 1992, 1993a, b, 1994a, b; Emi et al., 1992; Inazawa et al., 1993; Nakamura et al., 1994; Ariyama et al., 1995).

\section{Mapping of the loci for tumor suppressor genes}

To investigate the loci that contain tumor suppressor genes, we have examined a large number of sporadic carcinomas of the lung, esophagus, liver, ovary, breast, and kidney for loss of heterozygosity $(\mathrm{LOH})$, using polymorphic DNA markers representing all autosomal chromosomes (Fujimori et al, 1991; Morita et al., 1991; Sato et al., $1991 \mathrm{a}, \mathrm{b}$; Tsuchiya et al., 1992; Aoki et al., 1994). In esophageal squamous cell carcinomas, allelic losses at frequencies of at least $30 \%$ were observed at loci on chromosomal arms 3p (33\%), 3q (30\%), 5q (36\%), 9p (57\%), 9q $(60 \%), 10 p(33 \%), 13 q(43 \%), 17 p(62 \%), 17 q(46 \%), 18 q(38 \%), 19 q(32 \%)$, and $21 q$ (37\%), suggesting that several putative tumor suppressor genes associated with development and/or progression of esophageal cancer on these chromosomal arms. By a comparison of LOH on each chromosomal arm with clinicopathological parameters of patients, we have found that the frequency of $\mathrm{LOH}$ on $17 \mathrm{q}$ was significantly higher in tumors in female patients (12 of 14 cases) than in those in male patients ( 20 of 56 cases) ( $p=0.0009$ by Fisher's exact test). In hepatocellular carcinomas, we found that a putative tumor suppressor genes for HCC are likely to be located on chromosome $5 \mathrm{q}, 10 \mathrm{q}, 11 \mathrm{p}, 16 \mathrm{q}$ and $17 \mathrm{p}$. In renal cell carcinoma (RCC), our results implicated a presence of tumor suppressor genes on seven chromosomal arms, chromosomes 3p, 5q, 6q, 10q, 11q, 17p, and 19p. In ovarian cancers, frequent LOHs were observed on chromosomes $4 p, 6 p, 7 p, 8 q, 12,16,17$, and $19 \mathrm{p}$.

\section{Isolation of the gene responsible for familial adenomatous polyposis (FAP)}

Familial adenomatous polyposis (FAP) is an autosomal-dominant disease, that affects 1 in 7,000-15,000 people worldwide. FAP is characterized by development of hundreds to thousands of adenomatous polyps in the colon and rectum, one or more of which will progress to cancer if left without surgical treatment. Cytogenetic observation in one FAP patient (Herrera et al., 1986) and linkage studies in large FAP kindreds (Bodmer et al., 1987; Leppert et al., 1987; Nakamura et al., 1988f) localized the gene responsible for FAP to chromosome $5 \mathrm{q} 21-22$.

By means of "positional cloning," we and others succeeded in identifying the gene responsible for FAP, termed the APC (adenomatous polyposis coli) gene, which codes 2843 amino acids (Kinzler et al, 1991; Nishisho et al., 1991; Groden et al., 1991; Joslyn et al., 1991). The APC gene is expressed ubiquitously in various organs, but at least five forms of non-coding transcripts have been identified (Horii et al., 1993). We have investigated germline mutations in patients with FAP. The mutations of the APC gene was found in $70 \%$ of 150 FAP patients 
that were screened the entire coding region by an RNase protection assay. Of the 106 APC germ-line mutations that we detected, 66 were $1-8$ bp deletions and three were 1-2 bp insertions; all caused a shift of the APC reading frame, that created new stop codons downstream. Of 39 point mutations, 33 generated stop codons and six led to amino acid substitutions. One was intronic sequence deletion that could affect a splicing. Thus, $100(94 \%)$ of the 106 mutations so far detected were predicted to result in truncation of the APC protein (Nagase and Nakamura, 1993; Nakamura, 1993). Only 6\% of the mutations so far found were considered to induce substitution of an amino acid. These results have implied that detection of truncated APC protein by antibody may be an easy and simple method for presymptomatic diagnosis of individuals carrying APC mutations.

It is well known that deletions often occur where nucleotides are repeated, perhaps because of mis-alignment. Our observations, which included a $\mathrm{C}$ deletion from CCC (at codon 1427), an A deletion from several A's (codon 142) and an AA from AAA (codon 1250), were consistent with a proposed model for generating mis-alignment within a stretch of common bases. Some of other deletions in APC have occurred at positions containing multiple copies of a direct repeat; for example, a 2-base deletion from a sequence containing five AG repeats (AAAGAGAGAGAGTG; codon 1465), a 5-base (AAAGA) deletion at ATAAAAGAAAAGATT (codon 1309); a 5-base (ACAAA) deletion from ATAAAACAAAGT (codon 1061), and a TGAAA deletion from TCAAATGAAAAC (codon 1546) have been detected. All of these deletions may have occurred during DNA replication, probably as a result of slippage of the template strand and subsequent mis-alignment. After synthesis of the first copy of the direct repeat, the template strand could slip and mis-align with the second copy of the repeat, with the result that the intervening sequences would be deleted.

Comparisons of germ-line mutations with clinical manifestations other than colorectal polyposis, in 29 FAP patients for whom detailed information was available. Although FAP is frequently accompanied by extra-colonic manifestations, observations of variable phenotypes of patients within single pedigrees have suggested that extra-colonic manifestations are not regulated simply by the mutation causing a large number of polyps in colon and rectum. Our results support the view that extra-colonic manifestations, i.e. osteomas, epidermoid cyst, desmoid tumors, thyroid tumors, and upper gastrointestinal polyps do not correlate with the type or location of a particular germ-line mutation. We also compared the locations of germ-line APC mutations in 25 unrelated patients with the number of colorectal polyps developed in each case; 19 patients were sparse types and six were profuse types. All but one of the mutations were considered to cause truncation of the gene product by frame-shift, due to deletion or nonsense mutation (Nagase et al., 1992a, b). The location of each germ-line mutation seemed to correlate with clinical type; mutations in the FAP patients with profuse polyps were observed between codons 1250 and 1464 , whereas mutations in the 
FAP patients with fewer polyps had occurred in other regions of the APC gene. The result suggests that the number of colorectal polyps in FAP patients may be associated with a difference in the stability or the biological function of the truncated APC protein.

\section{Somatic mutations of the APC gene}

Extensive screening for somatic mutations of the APC gene has been carried out in colorectal tumors. Our group has screened 160 colorectal adenomas and carcinomas, including 87 from FAP patients, and found 98 somatic mutations (Nishisho et al., 1991; Miki et al., 1992; Miyoshi et al., 1992; Ichii et al., 1992, 1993). Thirty-nine of the 98 somatic mutations have been point mutations; 32 nonsense, seven missense. Twenty-one of 39 occurred at $\mathrm{C}$ residues; nine were at $\mathrm{CpG}$ sites, in a ratio similar to that observed in germ-line mutations. Fifty-six were frameshift mutations consisting of 42 deletions and 14 insertions. Three were intronic sequence deletions. Like the germ-line mutations, most (91 of 98) of these somatic mutations are predicted to truncate the APC products.

We have also detected somatic mutations of the APC gene in 13 of 91 gastric cancers examined and in three of 10 pancreatic cancers (Horii et al., 1992a, b; Nakatsuru et al, 1992). Unlike germ-line mutations in FAP patients or somatic mutations in colorectal tumors, a half of the mutations detected in gastric cancers were missense mutations. Furthermore, three separate somatic mutations were detected in each of two gastric carcinomas; this finding is interesting because among the nearly 100 colorectal tumors examined, not one has been found to carry three mutations. Missense mutations in gastric carcinomas may indicate that one or more of specific mutagens, possibly in food participate in genetic alterations of gastric mucosal cells.

\section{Early genetic events during of colorectal carcinogenesis}

To examine early genetic events during colorectal carcinogenesis, we searched for genetic alterations in 75 adenomas from seven patients with familial polyposis coli (FAP) and in 64 sporadic colorectal tumors (63 carcinomas and one adenoma). We investigated germ-line and somatic mutations in the APC gene, somatic mutations in the K-ras (codons 12, 13, and 61) and p53 genes (exons 5-8), and loss of heterozygosity on the short arm of chromosome 8. Thirty-two FAP adenomas carried detectable somatic mutations in the APC gene. When the adenomas developed in FAP patients were divided into three groups based on their size $(<3 \mathrm{~mm}, 3-10 \mathrm{~mm}$, or $>10 \mathrm{~mm}$ ) or their pathohistological grade (mild, moderate, or severe dysplasia), the somatic APC mutations were detected even in adenomas of $<3 \mathrm{~mm}$ with moderate dysplasia while K-ras mutations were rare in these tumors. Hence, inactivation of both alleles of the APC gene is considered to play a significant role in development of colorectal adenoma. Mutation of the $\mathrm{p} 53$ gene was observed in only two adenomas and loss of heterozygosity ( $\mathrm{LOH}$ ) on 
8 p22 was detected in none. These results imply that a second "hit" in the APC gene, but not necessarily mutation in K-ras or p53, is an important and critical event for formation of a colorectal adenoma (Ichii et al., 1993).

\section{Genetic diagnosis of lymph-node metastasis of patients with colorectal cancer}

To apply the information of genetic alterations in colorectal cancers to clinical field, we have applied the mutant allele-specific amplification (MASA) method for detection of micrometastases to lymph nodes which are histologically diagnosed negative. To examine prognostic significance of genetically-detectable tumor cells in regional lymph nodes of colorectal cancer patients, we screened 120 colorectal cancers without histologically-detectable lymph node metastasis, for $\mathrm{K}$-ras (codon 12, 13, and 61) or p53 mutations (exons 5-8) and examined corresponding regional lymph node at the genetic level by the MASA method. All of the patients, who had no histologically-detectable lymph-node metastasis but had distant metastases or local recurrences after surgery, were genetically diagnosed lymph node positive. Genetically-positive lymph node metastases were found in all of the patients in the recurrence group, but in only $22.7 \%$ of those in the recurrencefree group, with a statistically significant difference $(\mathrm{p}<0.0001)$ (Hayashi et al., 1995). Hence, Genetic diagnosis of lymph node metastasis may become a useful prognostic factor and be a selective marker for post-operative intensive adjuvant chemotherapy.

\section{REFERENCES}

Aoki T, Mori T, XiQun D, Nishihira T, Matsubara T, Nakamura Y (1994): Allelotype study of esophageal carcinoma. Genes Chromosomes Cancer 10: 177-182

Ariyama T, Inazawa J, Ezaki T, Nakamura Y, Horii A, Abe T (1995): High-resolution cytogenetic mapping of the short arm of chromosome 1 with newly isolated 411 cosmid markers by fluorescence in situ hybridization: the precise order of 18 markers on $1 \mathrm{p} 36.1$ on prophase chromosomes and "stretched" DNAs. Genomics 25: 114-123

Bodmer WF, Bailey CJ, Bodmer J, Bussey HJR, Ellis A, Gorman P, Lucibello FC, Murday VA, Rider SH, Scambler P, Sheer D, Solomon E, Spurr NK (1987): Localization of the gene for familial adenomatous polyposis on chromosome 5. Nature (London) 328: 614-616

Emi M, Koyama K, Okui K, Takahashi E, Oshimura M, Nakamura Y (1992): Isolation and mapping of 88 new RFLP markers on human chromosome 8. Genomics 13: 1261-1266

Fujimori M, Tokino T, Hino O, Kitagawa T, Imamura T, Okamoto E, Mitsunobu M, Ishikawa T, Nakagama H, Harada H, Yagura M, Matsubara K, Nakamura Y (1991): Allelotype study of primary hepatocellular carcinoma. Cancer Res 51: 89-93

Gatti R, Nakamura Y, Nussmeier M, Susi E, Shan W, Grody W (1989): Informativeness of VNTR genetic markers for detecting chimerism after bone marrow transplantation. Dis Markers 7: 105-112

Groden J, Thliveris A, Samowitz W, Carlson M, Gelbert L, Albertsen H, Joslyn G, Stevens J, Spirio L, Robertson M, Sargeant L, Krapcho K, Wolff E, Burt R, Hughes JP, Warrington J, McPherson J, Wasmuth J, Paslier DL, Abderrahim H, Cohen D, Leppert M, White R 
(1991): Identification and characterization of the familial adenomatous polyposis coli gene. Cell 66: $589-600$

Gyapay G, Morissette J, Vignal A, Dib C, Fizames C, Millasseau P, Marc S, Bernardi G, Lathrop M, Weissenbach J (1994): The 1993-1994 Genethon human genetic linkage map. Nature Genet 7: 246-339

Hayashi N, Ito I, Yanagisawa A, Kato Y, Nakamori S, Imaoka S, Watanabe H, Ogawa M, Nakamura $Y$ (1995): Genetic diagnosis of lymph-node metastasis allows accurate prognosis of patients with colorectal cancer. Lancet 345: 1257-1259

Herrera L, Kakati S, Gibas L, Pietrzak E, Sandberg AA (1986): Gardner syndrome in a man with an interstitial deletion of 5q. Am J Med Genet 25: 473-476

Hori T, Takahashi E, Tanigami A, Tokino T, Nakamura Y (1992): A high-resolution cytogenetic map of 168 cosmid DNA markers for human chromosome 11. Genomics 13: 129-133

Horii A, Nakatsuru S, Miyoshi Y, Ichii S, Nagase H, Kato Y, Yanagisawa A, Nakamura Y (1992a): The APC gene, responsible for familial adenomatous polyposis, is mutated in human gastric cancer. Cancer Res 52: 3231-3233

Horii A, Nakatsuru S, Miyoshi Y, Ichii S, Nagase H, Ando H, Yanagisawa A, Tsuchiya E, Kato Y, Nakamura Y (1992b): Frequent somatic mutation of the APC gene in human pancreatic cancer. Cancer Res 52: 6696-6698

Horii A, Nakatsuru S, Ichii S, Nagase H, Nakamura Y (1993): Multiple forms of the APC gene transcripts and their tissue-specific expression. Hum Mol Genet 2: 283-287, 1993

Ichii S, Horii A, Nakatsuru S, Furuyama J, Utsunomiya J, Nakamura Y (1992): Inactivation of both APC alleles in an early stage of colon adenomas in a patient with familial adenomatous polyposis (FAP). Hum Mol Genet 1: 387-390

Ichii S, Takeda S, Horii A, Nakatsuru S, Miyoshi Y, Emi M, Fujiwara Y, Koyama K, Furuyama J, Utsunomiya J, Nakamura Y (1993): Detailed analysis of genetic alterations in colorectal tumors from patients with and without familial adenomatous polyposis (FAP). Oncogene 8: $2399-2405$

Inazawa J, Saito H, Ariyama T, Abe T, Nakamura Y (1993): High-resolution cytogenetic mapping of 342 new cosmid markers on human chromosome 17 by fluorescent in situ hybridization. Genomics 17: 153-162

Joslyn G, Carlson M, Thliveris A, Albertsen H, Gelbert L, Samowitz W, Groden J, Stevens J, Spirio L, Robertson M, Sargeant L, Krapcho K, Wolff E, Burt R, Hughes JP, Warrington J, McPherson J, Wasmuth J, Paslier DL, Abderrahim H, Cohen D, Leppert M, White R (1991): Identification of deletion mutations and three new genes at the familial polyposis locus. Cell 66: 601-613

Julier C, Nakamura Y, Lathrop M, O'Connell P, Leppert M, Mohandas T, Lalouel J-M, White R (1990a): A primary map of 24 loci on human chromosome 16. Genomics 6: 419-427

Julier C, Nakamura Y, Lathrop M, O'Connell P, Leppert M, Litt M, Mohandas T, Lalouel J-M, White R (1990b): A detailed genetic map of the long arm of chromosome 11. Genomics 7: 335-345

Kasai K, Nakamura Y, White R (1990): Amplification of a VNTR locus (pMCT118) by the polymerase chain reaction (PCR) and its application to forensic science. J Forensic Sci 35: $1196-1200$

Kinzler KW, Nilbert MC, Su L, Vogelstein B, Bryan TM, Levy DB, Smith KJ, Preisinger AC, Hedge P, McKechnie D, Finniear R, Markham A, Groffen J, Boguski MS, Alschul SF, Horii A, Ando H, Miyoshi Y, Miki Y, Nishisho I, Nakamura Y (1991): Identification of FAP locus genes from chromosome 5q21. Science 253: 661-665

Lathrop M, Nakamura Y, Cartwright P, O'Connell P, Leppert M, Jones C, Tateishi H, Bragg T, Lalouel J-M, White R (1988a): A primary genetic map of markers for human chromosome 10. Genomics 2: 157-164 
Lathrop M, Nakamura Y, O'Connell P, Leppert M, Woodward S, Lalouel J-M, White R (1988b): A mapped set of genetic markers for human chromosome 9. Genomics 3: 361-366

Lathrop M, O'Connell P, Leppert M, Nakamura Y, Farrall M, Tsui L-C, Lalouel J-M, White R (1989): Twenty-five loci form a continuous linkage map of markers for human chromosome 7. Genomics 5: 866-873

Leppert M, Dobbes M, Scambler P, O'Connell P, Nakamura Y, Stauffer D, Woodward S, Burt R, Hughes J, Gardner E, Lathrop M, Wasumuth J, Lalouel J-M, White R (1987): The gene for familial polyposis coli maps to the long arm of chromosome 5. Science 238: 1411-1413

Miki Y, Nishisho I, Horii A, Miyoshi Y, Utsunomiya J, Kinzler K, Vogelstein B, Nakamura Y (1992): Disruption of the APC gene by retrotransposal insertion of L1 sequence in a colon cancer. Cancer Res 52: 643-645

Miyoshi Y, Nagase H, Ando H, Horii A, Ichii S, Nakatsuru S, Aoki T, Miki Y, Mori T, Nakamura Y (1992): Somatic mutation of the APC gene in colorectal tumors: mutation cluster region in the APC gene. Hum Mol Genet $1: 229-233$

Morita R, Ishikawa J, Tsutsumi M, Hikiji K, Tsukada Y, Kamidono S, Maeda S, Nakamura Y (1991): Allelotype of renal cell carcinoma. Cancer Res 51: 820-823

Nagase H, Miyoshi Y, Horii A, Aoki T, Ogawa M, Utsunomiya J, Baba S, Sasazuki T, Nakamura Y (1992a): Correlation between the location of germ-line mutations in the APC gene and the number of colorectal polyps in familial adenomatous polyposis (FAP) patients. Cancer Res 52: $4055-4057$

Nagase H, Miyoshi Y, Horii A, Aoki T, Petersen GM, Vogelstein B, Maher E, Ogawa M, Utsunomiya J, Baba S, Nakamura Y (1992b): Screening for germ-line mutations in familial adenomatous polyposis (FAP) patients: 61 new patients and a summary of 150 unrelated patients. Hum Mutat 1: 467-473

Nagase H, Nakamura Y (1993): Mutations of the APC (adenomatous polyposis coli) gene. Hum Mutat 2: $425-434$

Nakamura Y, Leppert M, O'Connell P, Wolff R, Holm T, Culver M, Martin C, Fujimoto E, Hoff M, Kumlin E, White R (1987): Variable Number of Tandem Repeat (VNTR) markers for human gene mapping. Science 235: 1616-1622

Nakamura Y, Carlson M, Krapcho K, Kanamori M, White R (1988a): A new approach for isolating VNTR markers. Am J Hum Genet 43: 854-859

Nakamura Y, Lathrop M, O'Connell P, Leppert M, Barker D, Wright E, Skolnick M, Kondoleon S, Litt M, Lalouel J-M, White R (1988b): A mapped set of DNA markers for human chromosome 17. Genomics 2: 302-307

Nakamura Y, Lathrop M, O'Connell P, Leppert M, Lalouel J-M, White R (1988c): A primary map of 10 DNA markers and 2 serological markers for human chromosome 19. Genomics 2: $67-71$

Nakamura Y, Lathrop M, O'Connell P, Leppert M, Lalouel J-M, White R (1988d): A mapped set of markers for human chromosome 15. Genomics 3: 342-346

Nakamura Y, Lathrop M, Bragg T, Jones C, O'Connell P, Leppert M, Lalouel J-M, White R (1988e): An extended linkage map for human chromosome 10. Genomics 3: 389-392

Nakamura Y, Lathrop M, Leppert M, Dobbes M, Wasumuth J, Wolff E, Carlson M, Fujimoto E, Krapcho K, Woodward S, Burt R, Hughes J, Gardner E, Lalouel J-M, White R (1988f): Localization of the genetic defect in familial adenomatous polyposis within a small region of chromosome 5. Am J Hum Genet 43: 638-644, 1988

Nakamura Y, Lathrop M, O'Connell P, Leppert M, Lalouel J-M, White R (1989a): Frequent recombination was observed in the distal end of the long arm of human chromosome 14. Genomics 4: 76-81

Nakamura Y, Leppert M, O'Connell P, Lathrop M, Lalouel J-M, White R (1989b): A genetic linkage map of markers for human chromosome 20. Genomics 5: 945-947 
Nakamura Y (1993): The role of the APC (adenomatous polyposis coli) gene in human cancers. Adv Cancer Genet 62: 65-87

Nakamura Y, Okui K, Takahashi E, Koyama K (1994): Isolation and mapping of 328 new cosmid markers on human chromosome 8: construction of a high resolution cytogenetic map of chromosome 8 with 416 markers. Cytogenet Cell Genet 65: 115-118

Nakatsuru S, Yanagisawa A, Ichii S, Tahara E, Kato Y, Nakamura Y, Horii A (1992): Somatic mutation of the APC gene in gastric cancer: frequent mutations in very well differentiated adenocarcinoma and signet-ring cell carcinoma. Hum Mol Genet 1: 559-563

NIH/CEPH Collaborative Mapping Group (1992): A comprehensive genetic linkage map of the human genome. Science 258: 67-86

Nishisho I, Nakamura Y, Miyoshi Y, Miki Y, Ando H, Horii A, Koyama K, Utsunomiya J, Baba S, Hedge P, Markham A, Krush AJ, Petersen G, Hamilton SR, Nilbert MC, Levy DB, Bryan TM, Preisinger AC, Smith KJ, Su L, Kinzler KW, Vogelstein B (1991): Mutations of chromosome 5q21 genes in FAP and colorectal cancer patients. Science 253: 665-669

O'Connell P, Lathrop M, Leppert M, Nakamura Y, Muller U, Lalouel J-M, White R (1989a): Twelve loci form a continuous linkage map for human chromosome 18. Genomics 3: 367372

O’Connell P, Lathrop M, Nakamura Y, Leppert M, Ardinger RH, Murray JL, Lalonel J-M, White R (1989b): Twenty-eight loci form a continuous linkage map of markers for human chromosome 1. Genomics 4: 12-20

O'Connell P, Lathrop M, Nakamura Y, Leppert M, Lalouel J-M, White R (1989c): Twenty loci form a continuous linkage map of markers for human chromosome 2. Genomics 5: 738-745

Odelberg SJ, Plaetke R, Eldridge JR, Ballard L, O'Connell P, Nakamura Y, Leppert M, Lalouel J-M, White R (1989): Characterization of VNTR loci by high-resolution agarose gel electrophoresis: implications for parentage testing and forensic individualization. Genomics 5: 915924

Sato T, Saito H, Morita R, Koi S, Lee JH, Nakamura Y (1991a): Allelotype of human ovarian cancer. Cancer Res 51: $5118-5121$

Sato T, Akiyama F, Sakamoto G, Kasumi F, Nakamura Y (1991b): Accumulation of genetic alterations and progression of primary breast cancer. Cancer Res 51: 5794-5799

Takahashi E, Yamakawa K, Nakamura Y, Hori T (1992): A high resolution cytogenetic map of human chromosome 3: localization of 292 new cosmid markers by a direct mapping system with fluorescence in situ hybridization. Genomics 13: 1047-1055

Takahashi E, Hitomi S, Koyama K, Nakamura Y (1993a): A high-resolution cytogenetic map of human chromosome 5: localization of 206 new cosmid markers by direct R-banding fluorescence in situ hybridization. Genomics 17: 234-236

Takahashi E, Koyama K, Hitomi S, Nakamura Y (1993b): A high-resolution cytogenetic map of human chromosome 12: localization of 195 new cosmid markers by direct R-banding fluorescence in situ hybridization. Hum Genet 92: 405-409

Takahashi E, Koyama K, Hitomi A, Itoh H, Nakamura Y (1994a): A high-resolution cytogenetic map of human chromosome 9: localization of 203 new cosmid markers by direct R-banding fluorescence in situ hybridization. Genomics 19: 373-375

Takahashi E, Koyama K, Hirai M, Itoh H, Nakamura Y (1994b): A high-resolution cytogenetic map of human chromosome 2: localization of 434 cosmid markers by direct R-banding fluorescence in situ hybridization. Cytogenet Cell Genet 68: 112-114

Tsuchiya E, Nakamura Y, Weng S, Nakagawa K, Tsuchiya S, Sugano H, Kitagawa T (1992): Allelotype of non-small cell lung carcinoma-comparison of loss of heterozygosity between squamous cell carcinoma and adenocarcinoma. Cancer Res 52: 2478-2481

White R, Lalouel J-M, Leppert M, Lathrop M, Nakamura Y, O'Connell P (1989): Linkage maps of human chromosomes. Genome 31: 1066-1072

Vol. 41, No. 1, 1996 
Yamakawa K, Takahashi E, Saito H, Sato T, Oshimura M, Hori T, Nakamura Y (1991a): Isolation and mapping of 75 new DNA markers on human chromosome 3. Genomics 9: 536543

Yamakawa K, Morita R, Takahashi E, Lathrop M, Nakamura Y (1991b): A genetic linkage map of 41 RFLP markers for human chromosome 3. Genomics 11: 565-572 